\title{
INSECT PESTS OF SOYBEAN (GLYCINE MAX L.), THEIR NATURE OF DAMAGE AND SUCCESSION WITH THE CROP STAGES
}

\author{
G.C. BISWAS \\ Oilseed Research Centre, \\ Bangladesh Agricultural Research Institute, \\ Joydebpur, Gazipur-1701, Bangladesh
}

\begin{abstract}
Thirty nine species of insect pests were found to infest soybean crop at their different growth stages in Noakhali region of Bangladesh during January to May, 2010 and 2011. Among the recorded pest species, six species namely, hairy caterpillar, Spilarctia obliqua (Walker); leaf roller, Lamprosema indicata F; common cutworm, Spodoptera litura F; pod borer, Helicoverpa armigera (Hubner); stem fly, Ophiomyia phaseoli (Tryon) and white fly; Bemisia tabaci Genn. were considered as the major pests while the rests were of minor importance on the basis of population densities per plant, nature and extent of damages, and yield reductions. Most of the major and minor pests appeared in the crop during vegetative to flowering stages (30-50 Days after sowing) and the maximum insect population and their infestation occurred during flowering and pod formation stages of the crop throughout the study period.
\end{abstract}

Key words: Insect pests, Soybean, Glycine max, Damage, Succession, Crop stages

\section{Introduction}

Soybean (Glycine $\max$ L.) is one of the most important crops which is grown for oil and protein in both the rabi and kharif seasons. Seeds of soybean contain about $42 \%$ protein and $20 \%$ oil and provide $60 \%$ of the world supply of vegetable protein and $30 \%$ of the edible oil (Fehr 1989). In Bangladesh this crop is comparatively new but soybean oil is very much popular as edible oil. However, recently the crop gained popularity in the poultry industry and its cultivation expands day by day. In the Greater Noakhali region ( Noakhali and Laxmipur districts) soybean is the major oilseed crop and is extensively cultivated. Cultivation of soybean covered about 55,000 hectares of land and produced about 90,000 metric tones of seeds during the period 2009-2010 in Bangladesh (Anonymous 2011). One of the major constraints to the successful soybean production in Bangladesh is the damage caused due to insect pests. Research experiences reveal that 15 - 20 percent of the total soybean production is lost directly or indirectly by the attack of insect pests every year (Biswas 2008).

In order to evolve economically feasible, ecologically sound and socially acceptable pest management strategies, detailed information on the pest complex, their status and sequence of appearance during the crop period, losses and type of damage are of great importance (Jayanthi et al. 1993). In Bangladesh, check lists of insect pests of soybean and their succession in relation to crop stages are scanty. Only the list of some insect 
pests of soybean in Bangladesh was recorded (Sardar and Debnath 1984, Kaul and Das 1986, Ali 1988, Begum 1995, Biswas et al. 2001 and Biswas 2008). Therefore, the present research work was undertaken to record the insect pests of soybean, their nature of damage, incidence, infestation and time of appearance with the crop stages.

\section{Materials and Methods}

The research work was conducted in the field of Subarna Char, at Noakhali and in the laboratory of Oilseed Research Centre, BARI, Gazipur during rabi 2009-2010 and 20102011 crop seasons. The survey was conducted from one hectare land soybean field cultivated by the farmers with the supervision of scientists of Oilseed Research Centre, BARI, Joydebpur, Gazipur. The experimental plot measured $10 \mathrm{~m} \mathrm{X} 10 \mathrm{~m}$. The seeds of soybean were sown in the plots on $4^{\text {th }}$ week of December of 2009 and 2010 . There were four replications and plots were selected following a Randomize Complete Block Design. The rows and plants were spaced $30 \mathrm{~cm}$ and $10 \mathrm{~cm}$ apart, respectively. The recommended agronomic practices for raising the crop were maintained following the work of Mondal and Wahhab (2001).

Observation on species of insect pests with their population per plant was recorded from seedling to matured stage of the crop from 10 randomly selected samples of the plants in each plot. The time of appearance of the pests were observed and recorded. The nature of damage and feeding behaviour of the insects were carefully observed and their photographs were taken in the crop fields and in the laboratory. The recordings of data were included visual observations, hand tens, and hand picking of insects from the standing crops during 7:00-10:00 a.m and 4:00-6:00 p.m at weekly intervals. Some insects were also collected by aspirators for laboratory studies. The collected insects were preserved in the insect box and vial having $75 \%$ alcohol for identification. Relative population of insect was counted as suggested by Biswas et al. (2001). The collected insects were also reared in the laboratory at an ambient temperature $\left(24-34^{\circ} \mathrm{C}\right)$ in cages and preserved in the insect boxes. The insects (specimens) were preliminarily identified following Maxwell- Lefroy (1909), Borror et al. (1975), Fletcher (1985), Nair (1986), Singh (1990) and Biswas (2008). The insects were graded as major and minor on the basis of their population density per plant, nature and extent of damage of the crop and the yield reduction. The insect pests were also grouped as stem feeders, leaf feeders, leaf roller, sap sucker and borer on the basis of their feeding behaviour.

\section{Results and Discussion}

Pest complex of soybean: Thirty nine species of insect pests belonging to seven orders and 22 families were found to infest at the different growth stages of soybean crop in Noakhali region, Bangladesh during rabi seasons of two consecutive years 2009-10 and 2010-11(Table 1). Of these, only six species namely, hairy caterpillar, Spilarctia obliqua (Walker); leaf roller, Lamprosema indicata F.; common cutworm, Spodoptera litura F.; 
Table 1. Insect pests recorded from soybean crop ecosystems at Noakhali region, Bangladesh during 2009-10 and 2010-11 crop seasons.

\begin{tabular}{|c|c|c|c|c|c|}
\hline $\begin{array}{l}\text { SL } \\
\text { no. }\end{array}$ & Common Name & $\begin{array}{l}\text { Scientific } \\
\text { Name } \\
\end{array}$ & Order & Family & $\begin{array}{l}\text { Feeding } \\
\text { behaviour }\end{array}$ \\
\hline 01. & Hairy caterpillar & Spilarctia obliqua (Walker) & Lepidoptera & Arctiidae & Leaf eater \\
\hline 02. & erpillar & Anarsia ephippias (Mullar) & Lepidoptera & Arctiidae & Leaf eater \\
\hline 03. & Common cutworm & Spodoptera litura Fab. & Lepidoptera & Noctuidae & $\begin{array}{l}\text { Leaf eater \& } \\
\text { cutter }\end{array}$ \\
\hline 04. & Common cutworm & Spodoptera exigua Fab. & Lepidoptera & Noctuidae & $\begin{array}{l}\text { Leaf eater \& } \\
\text { cutter }\end{array}$ \\
\hline 05. & Leaf roller & Lamprosema indicata $\mathrm{F}$. & Lepidoptera & Pyralidae & $\begin{array}{l}\text { Leaf roller \& } \\
\text { eater }\end{array}$ \\
\hline 06. & Stem fly & $\begin{array}{l}\text { Ophiomyia phaseoli } \\
\text { (Tryon.) }\end{array}$ & Diptera & Agromyzidae & Stem borer \\
\hline 07. & Shoot fly & $\begin{array}{l}\text { Melanagromyza obtuse } \\
\text { Mach }\end{array}$ & Diptera & Agromyzidae & Shoo \\
\hline 08. & Wl & ia tabaci Genn. & Dipt & & cker \\
\hline 09. & er & erpa at & Lepic & Noc & Pod \\
\hline 10. & tworm & Agrotis ipsilon (Hufn.) & Lepidoptera & Noctuidae & Stemcutter \\
\hline 11. & Leaf & teryx spp. & Lepidc & Gelechiida & $\begin{array}{l}\text { Miner } \\
\text { \&eater }\end{array}$ \\
\hline 12. & er & richalc & Le & Noc & Lea \\
\hline 13. & Gree & Attractomorpha crenulata $\mathrm{F}$. & Orthe & Acrididae & Leaf \\
\hline 14. & $\begin{array}{l}\text { Longhorn grass } \\
\text { hopper }\end{array}$ & acilli Bur. & Orthol & Tettigonidae & Leaf \\
\hline 15. & stink bug & iridulc & $a$ & & Sap \\
\hline 16. & & oris $s$ & & & ker \\
\hline 17. & ug & $s$ Stal. & $\mathrm{ra}$ & e & ker \\
\hline 18. & & coris & Hete & Pent & Sap \\
\hline 19. & & na cribrarium $\mathrm{F}$. & era & Plata & Sap \\
\hline 20. & ug & isa spp. & Hete & ae & ker \\
\hline 21. & $\mathrm{Co}$ & s pedestris $\mathrm{F}$. & Hete & & ker \\
\hline 22. & on bug & us cingulatus $\mathrm{F}$. & era & $\mathrm{Py}$ & ker \\
\hline 23. & & raccivora (Koch) & era & Aphi & cker \\
\hline 24. & hopper & Aphannus sordidus F. & Hom & Jass & cker \\
\hline 25. & & Empoasca sp. & Hon & lae & cker \\
\hline 26. & & a biguttu & era & $\mathrm{ae}$ & cker \\
\hline 27. & & Pseudococcus corymbatlus & & lae & cker \\
\hline 28. & & Pseudococcus filamentosus & Hom & Coccidae & cker \\
\hline 29. & wn hopper & Nilaparvata lugens & Hom & Jassidae & Sap sucker \\
\hline 30. & & Frankliniella schultzei & Thysanoptera & Thripidae & Sap sucker \\
\hline 31. & Black w & Cyrtozemia cognate Marsal & Coleoptera & Culculioni & Leaf eater \\
\hline 32. & Grey weevil & Myllocerus discolor Boh. & Coleoptera & Culculionidae & Leaf eater \\
\hline 33. & W & Tenymecus indicus Fst. & Coleoptera & Culculionidae & Leaf eater \\
\hline 34. & Weevil & Chaetocnema sp. & Coleoptera & Halticidae & Leaf eater \\
\hline 35. & Pumkin & Aulacophora sp. & Coleoptera & Chysomelidae & Leaf eater \\
\hline 36. & Leaf beetle & Oulema sp. & Coleoptera & Chysomelidae & Leaf eater \\
\hline 37. & Leaf beetle & Monolepta signata Olv. & Coleoptera & Chysomelidae & Leaf eater \\
\hline 38. & Epilachna beetle & Epilachna 12-punctata & Coleoptera & Chysomelidae & Leaf eater \\
\hline 39. & Girdle beetle & Oberia brevis S. & Coleoptera & Chysomelidae & Leaf eater \\
\hline
\end{tabular}


pod borer, Helicoverpa armigera (Hubner); stem fly, Ophiomyia phaseoli (Tryon) and white fly, Bemisia tabaci Genn. were considered as the major pests while the rests were of minor importance on the basis of population densities per plant, nature and extent of damages and yield reductions. The population density per plant of major and minor insects and their rate of infestation on soybean plant is presented in Table 2. The population density per plant of major insects namely, S.obliqua, L. indicata, .S. litura, $H$. armigera, $O$. phaseoli and B.tabaci ranged from 0.50-0.60, 2.00-2.50, 1.50-1.80, $0.35-0.40,0.40-0.50$ and $4.00-5.00$, respectively in 2010 while it ranged from $0.45-0.55$, 1.50-2.00,1.20-1.50,0.30-3.50, 0.30-0.40 and 3.00-3.50, respectively in 2011. Similarly, percent plant infestation by the major insects namely, S.obliqua, L. indicata, S. litura, H. armigera, O. phaseoli and B. tabaci ranged from 70-80, 95-100, 90-100, 35-40, 40$45,96-100$, respectively in 2010 while it ranged from 60-70, 95-100, 80-90, 30-35, 35-40 and 95-100, respectively in 2011. Most of the number of major and minor pests per plant of soybean with their infestation rate was found higher in 2010 than in 2011 (Table 2). About 100 percent plant was infested by leaf roller, white fly, leaf hopper and leaf beetle throughout the study period. The higher insect population and their infestation in 2010 may be due to higher temperature, lower relative humidity and rainfall in 2010 than 2011 which provided suitable conditions for the population build-up of the insect pests.

Among the minor pests, green stink bug (Nezara viridula L.), semilooper (Plusia orichalcea Fab.), Black cutworm (Agrotis ipsilon ( Hufn.), leaf miner ( Stomopteryx spp.), green grasshopper (Attractomorpha crenulata F.), pod bug (Eusarcocoris sp.) and aphid (Aphis cracraccivora) became occassionally important and caused serious damage to the soybean crop. Aphid, jassid and whitefly are also important as vectors for transmission of viral (YMV) diseases (Biswas 2008).

On the basis of feeding behaviour, 17 species were grouped as sap sucker, 15 as leaf eater, 2 as leaf roller and eater, and the remaining five such as, Helicoverpa armigear, as pod borer and eater, Stomopteryx sp. as leaf miner, Agrotis sp. as stem cutter, Ophiomyia phaseoli and Melanagromyza obtusa as stem or shoot borers.

Nature of damage of the important pests: The $1^{\text {st }}$ and $2^{\text {nd }}$ instar larvae of $S$. obliqua damaged the soybean leaves and shoots and gregariously occurred in the same plants and leaves. Later on, $3^{\text {rd }}$ and onward instars dispersed and moved from one plant to another and fed on the older leaves, stems, shoots, flowers and pods causing serious damage to the plants. The yellowish green larvae of leaf roller rolled the leaves of soybean plants and several may be webbed together and feed inside. Damaged leaves became silverybrown papery. About 2-3 larvae remained in a single folded leaf. The pale green larvae of $S$. litura damaged the leaves and shoots by feeding voraciously. Infested leaves beared irregular holes, growth of the plant was arrested, flower and pod formation was hindered. Very small larvae of the pest bore into the stem through the petiole. They feed on cortex and pith of the stem causing tunneling of the stems and died. The green larvae of $H$. 
armigera feed on leaves and tender shoots firstly; later on they bore pods and feed inside. The green stink bugs suck sap from the tender shoots, leaves and pods resulting distorted leaves and pods.

Succession of the pests: The succession of the major insect pests of soybean crop during 2010 and 2011 at Noakhali region is presented in Fig.1. Soybean crop was first attacked by leaf beetle, Monolepta signata, black beetle, Cyrtozemia cognata, epilachna beetle, Epilachna 12 Punctata, E. 28 punctata, pumkin beetle, Aulacophorai sp., black cutworm, Agrotis ipsilon, leaf hopper, Aphannus sordidus, jassids, Empoasca spp. at the seedling stage and their infestation continued up to pod formation stage of the crop during January 2010 and 2011. After 2-3 weeks, leaf roller, Lamprosema indicata F. common cutworm, Spodoptera litura F. hairy caterpillar, S. obliqua, pod borer, Helicoverpa armigera Hubner, green stink bug, Nezara viridula L., rice bug and other pentatomid bugs were frequently observed from flowering to maturity of the crop and recorded on February to April 2010 and 2011.The bugs were also important which suck sap from the tender part of the stems, leaves and pods. The white fly and aphids were noticed from vegetative to pre-maturity of the crop and act as vectors of yellow mosaic virus (YMV) and leaf curled viruses that were seriously affected plant growth and yield of soybean crop in both the years. Stem fly was observed from seedling to pod formation stage of the crop while pod borer damage was recorded at the flowering and pod prematurity stage in both the years (Fig. 1).

\begin{tabular}{|c|c|c|c|c|c|}
\hline \multirow{5}{*}{$\begin{array}{c}\text { Duration/growth } \\
\text { stages }\end{array}$} & \multicolumn{5}{|c|}{ January $\longrightarrow$ February $\longrightarrow$ March $\longrightarrow$ April $\longrightarrow$} \\
\hline & \multicolumn{5}{|c|}{ Days after sowing } \\
\hline & 20 & 40 & 60 & 90 & 110 \\
\hline & \multicolumn{5}{|c|}{ Growth stages } \\
\hline & Seedling & Vegetative & \multirow[t]{2}{*}{ Flowering } & $\begin{array}{l}\text { Pod } \\
\text { formation }\end{array}$ & $\begin{array}{l}\text { Pod } \\
\text { maturity }\end{array}$ \\
\hline \multicolumn{5}{|l|}{ Hairy caterpillar } & \\
\hline \multicolumn{6}{|l|}{ Leaf roller } \\
\hline \multicolumn{6}{|l|}{ Common cutworm } \\
\hline \multicolumn{6}{|l|}{ Stem fly } \\
\hline \multicolumn{6}{|l|}{ Pod borer } \\
\hline \multicolumn{6}{|l|}{ White fly } \\
\hline \multicolumn{6}{|l|}{ Green stink bug } \\
\hline \multirow{2}{*}{\multicolumn{6}{|c|}{ Leaf hopper }} \\
\hline \multicolumn{5}{|l|}{ Semilooper } & \\
\hline \multicolumn{6}{|l|}{ Leaf beetle } \\
\hline \multicolumn{6}{|l|}{ Green grasshopper } \\
\hline \multicolumn{6}{|l|}{ Flower thrips } \\
\hline \multicolumn{6}{|l|}{ Grey weevil } \\
\hline \multicolumn{6}{|l|}{ Jassid } \\
\hline Aphid & & & & & \\
\hline
\end{tabular}

Fig. 1. Succession of important insect pests of soybean in relation to crop stages during 2010 and 2011 at Noakhali.

- The duration of occurrence of each species on the crop is shown by horizontal lines. 
The most damaging insects were hairy caterpillar, leaf roller, common cutworm, pod borer and stem flies those were found to damage during vegetative, flowering and pod formation stages (30-65 DAS) of the crop. The yield loss caused by these pests has been estimated more than $25 \%$ in Bangladesh. In the soybean field infestation of insect pests like stem flies, bugs, aphids and white fly were frequently observed. Stem flies (Ophiomyia phaseoli and Melanagromyza sojae) were the major pests of soybean and about $30 \%$ loss occurred due to attack of these pests in this country. About $25-30 \%$ pod was damaged by pod borer at the pod formation to prematurely of the crop. About $100 \%$ soybean plant and $70 \%$ leaf were infested by leaf roller and common cutworm and hairy caterpillar (Table 2).

Table 2. Population density per plant and percent infestation of some important insect pests of soybean crop during 2010 and 2011 at Noakhali region.

\begin{tabular}{l|cc|c|c|c}
\hline \multirow{2}{*}{ Name of insects } & \multicolumn{2}{|c|}{ No. of insect / plant } & \multicolumn{2}{c|}{ Plant infestation $\%$} & $\begin{array}{c}\text { Stage of severe } \\
\text { infestation }\end{array}$ \\
\cline { 2 - 5 } & 2010 & 2011 & 2010 & 2011 & \\
\hline Hairy caterpillar & $0.50-0.60$ & $0.45-0.55$ & $70-80$ & $60-70$ & F-P \\
Leaf roller & $2.00-2.50$ & $1.50-2.00$ & $95-100$ & $95-100$ & V-F \\
Common cutworm & $1.50-1.80$ & $1.20-1.50$ & $90-100$ & $80-90$ & V-F \\
Stem fly & $0.40-0.50$ & $0.30-0.40$ & $40-45$ & $35-40$ & S-V \\
Pod borer & $0.35-0.40$ & $0.30-0.35$ & $35-40$ & $30-35$ & F-M \\
White fly & $4.00-5.00$ & $3.00-3.50$ & $95-100$ & $95-100$ & V-P \\
Green stink bug & $0.60-0.80$ & $0.50-0.80$ & $70-75$ & $65-70$ & V-P \\
Leaf hopper & $3.50-4.50$ & $3.00-4.00$ & $95-100$ & $95-100$ & V-P \\
Semilooper & $0.30-0.40$ & $0.25-0.30$ & $40-50$ & $35-40$ & V-P \\
Leaf beetle & $2.50-3.50$ & $2.00-3.00$ & $96-100$ & $95-100$ & S-F \\
Green grasshopper & $0.30-0.40$ & $0.25-0.30$ & $40-45$ & $35-40$ & V-M \\
Flower thrips & $5.00-6.00$ & $4.00-5.50$ & $96-100$ & $95-100$ & F \\
Grey weevil & $0.25-0.30$ & $2.00-0.25$ & $25-30$ & $20-25$ & V-P \\
Jassid & $2.50-3.50$ & $2.00-3.00$ & $96-100$ & $95-100$ & V-P \\
Aphid & $4.50-5.50$ & $4.00-4.50$ & $60-70$ & $50-60$ & V-P \\
\hline
\end{tabular}

Data were recorded on average of 30 soybean plants.

V- Vegetative, S-Seedling, F-Flowering, P-Pod formation, M-Maturity.

The insect pests of soybean were recorded in Bangladesh by several scientists. Alam (1976) listed only four species of insect pests attacking the soybean. Of these, leaf roller (L. indicata F.) and mealy bug (Pseudococcus corymbatlus) were important. Sardar and Debnath (1984) recorded 15 species of insects of soybean crop in Bangladesh. Of these, bean bug, leaf roller, hooded hopper caused serious damage. Kaul and Das (1986) 
recorded 14 species of insect pests attacking soybean in Bangladesh. Of these, hairy caterpillar, cutworm, leaf roller (L. indicata F.) and bug (N.viridula L.) were recorded as major pests. From the survey report of Ali (1988) in the northern Bangladesh, it is revealed that 47 species of insect pests had been recorded in different stages of soybean crop in that area. Of these, 12 species were considered as serious pests. Begum (1995) listed 9 species of insects in soybean, Das (1998) recorded two major pests namely, hairy caterpillar and stem fly. Biswas (2008) recorded 35 species of insect pests attacking soybean at Gazipur all of which were also recorded in this study. Biswas et al. (2001) reported that leaf roller ( $L$. indicata) and hairy caterpillar $(S$. obliqua) were the major pests of soybean and about $80 \%$ plant and about $60 \%$ leaf were infested by the attack of these pests.

The succession of appearances of the insect pests on soybean showed that the population of different pest species occurred in an overlapping manner and the crop was under the continuous attack of one or more pests. Most of the major and minor pests appeared in the crop during vegetative to flowering stages (30-50 Days after sowing) and the maximum infestation occurred during flowering and pod formation stages of the crop in both the years. Although most of the insects recorded from soybean crop during the study period have been considered as minor, it is not unlikely that any one of the minor pests may attain the status of a major pest depending upon the environmental conditions and changing cropping pattern.

\section{References}

Anonymous, 2011. Krishi Diary-2011, Agricultural Information Service, Khamarbari, Farm Gate, haka-1215, pp.573.

Alam, M. Z. 1976. Insect pests of pulses and oilseeds and their storage problem. Proc. $1^{\text {st }}$ National Workshop on Oilseeds and Pulses, October 11-13, 1976. pp. 157-163. BARC, Farmgate, Dhaka.

Ali, M.I. 1988. A survey of the insect pests of soybean in Northern Bangladesh, their damage and occurrence. Tropical Pest Management. 34(3): 328-330.

Begum, S. 1995. Insect pests of oilseed crops of Bangladesh. Bangladesh J. Zool. 23: 153- 158.

Biswas, G.C. 2008. Insect pests and their management of soybean crop in Bangladesh. Proceedings of the Workshop on Prospects and Performance of Soybean in Bangladesh (M.A. Bakr ed.) ORC, BARI, Gazipur. pp.67.

Biswas, G.C., M.M. Hossain and U.K. Mazumder, 2001. Screening of some soybean lines against soybean leaf roller. Bangladesh J. Agril. Res. 26 (2): 295-300.

Borror, J.D., M.D. delong and C.A. Triplehorn. 1975. An Introduction to The Study of Insects. Holt, Rinehart and winston, New York. pp.852.

DAS, G. P. 1998. Major Insect and Mite Pests of Important Crops and Stored Products of Bangladesh. Bangladesh Agric. Res. Ins. Joydebpur, Gazipur-1701. pp.102.

Fehr, W.R. 1989. Soybean, importance and distribution pp. 283-300. In: Robblen. G.R.K. Downy and Ashri (ed). Oilcrops of the world. Mc-Grow-Hill Pub. Com. New York.

Fletcher, G.B. 1985. Annotatec list of Indian Crop Pests. Periodical Expert Book Agency, Vivek Vihar. Delhi. pp.282.

Jayanthi, M., K. M. Singh and R. N. Singh. 1993. Pest complex of high yielding groundnut variety MH4 under Delhi comdition. Indian J. Ent. 55(1): 30-33. 
Kaul, A. K. and M. L. Das. 1986. Oilseeds in Bangladesh. Bangladesh Canada Agriculture Sector Team. Ministry of Agriculture, Govt. of the People's Republic of Bangladesh, Dhaka. pp.324.

Mondal, M.R.I. and M.A. Wahhab. 2001. Production Technology of Oilcrops. Oilseed Research Centre, BARI, Joydebpu, Gazipur. pp. 111.

Maxwell-Lefroy, H. 1909. Indian Insect Life. A manual of the insects of the plain. Today and Tomorrow Printing and Publisher. New Delhi. pp. 786.

Nair, M.R.G.K. 1986. Insects and Mites of Crop in India. Indian Council of Agricultural Research New Delhi. pp. 408.

Sardar, M. A. and M. K. Debnath, 1984. An investigation into the insect pests of soybean with a note of chemical control of Nezara viridula. Bangladesh J. Agric. 9: $39-43$.

Singh, R.S. 1990. Insect Pest of Tropical Food Legumes. John Willey and Sons. New York, pp.451.

(Received revised manuscript on 4 February 2013) 